\section{SCIENCE TEACHING IN SECONDARY SCHOOLS}

The Teaching of Science in Secondary Schools Compiled by a Joint Committee of the Incorporated Association of Assistant Masters and the Science Masters' Association. Second edition, revised and reset. Pp. ix +274. (London: John Murray (Publishers), Ltd., 1958.) 17s. 6d. net.

7 HE original edition of this book dealt, in a practical manner, with every aspect of science teaching in the grammar type of secondary school. In the present edition every chapter has been revised thoroughly and the work is, in fact, a new book.

The original edition was the outcome of several years work by a committee which had the help of two hundred corresponding members. The present edition likewise is the fruit of the work of several years. Its appearance is timely, since so much thought is being devoted to the extension of scienceteaching and to the place of science in the school curriculum. In particular, the new edition will prove most valuable because of the immense fund of practical experience available to the compilers on the design and equipment of laboratories and science rooms. When new schools are built or old schools are improved, teachers who act in a consultative capacity will find in this book a useful guide towards a solution of the problems which beset modern teaching laboratory design.

The work begins with a short history of scienceteaching, and it is hoped that the future will see a separate volume dealing with the 'comparative' history of science teaching. It is useful to envisage the present system, with its difficulties and imperfections, through its history.

In the following chapter the aims of science-teaching are clearly stated. This is important, since so many so-called aims of education are entirely idealistic and theoretical. A pleasing feature of the book throughout its pages is that it keeps its feet firmly on the ground. Whereas the cultural value of science is stressed, its place in the competitive extra-mural world of technical achievement and economic survival is not forgotten.

Subsequent chapters deal in detail with the time desirable and available each year of the school course for teaching science, and the practical needs in the form of laboratories, demonstration, store and other rooms for schools of various sizes; plumbing, lighting, heating, ventilation, water, gas and electricity supplies are all considered in an expert manner. Even the acoustics of science rooms, floor materials, wall surfaces, doors, hatches and blackboards have reasonably adequate treatment.

There follows a chapter packed with information, presented succinctly, on apparatus and its maintenance, materials and safety precautions. Various methods of science-teaching are discussed and there is a very useful chapter on advanced-course work and preparation for university entrance. This is particularly valuable since the sixth forms of many smaller grammar schools are not adequately equipped, in materials and staff. A useful warning is given concerning the dangers of neglecting the mathematical background of the school sciences. Other sections deal with examinations, visual and other teaching aids, science in rural schools, first aid in the labora- tory, the supply and training of science teachers, the science teacher and the law. The work concludes with a comprehensive bibliography.

There are some sensible and encouraging remarks on the training of science teachers, though one wonders where men and women with all the qualities and qualifications, given as necessary for the teacher of potential teachers, ean be found.

The aims of 'methods' lecturers in science are twofold : "first, there is the immediate aim of suggesting to the beginner appropriate methods of approach, describing good techniques for handling material so that it may make its full contribution to the education of the pupils. Secondly, the 'methods' lecturer is often faced with the task of doing his best to correct the unfortunate bias of some university courses. For instance, in many universities students are turned out without any knowledge of laboratory technique and are entirely ignorant of the subject in which they have been trained. The university course often concentrates on teaching skills and techniques applicable mainly to elementary research. The 'methods' lecturer endeavours to correct this by emphasizing the social and historical bases of science and by stimulating thought on more fundamental problems concerning the implications of science".

Not only should every teacher and potential teacher of science know this important book; but also it should be read by every head teacher and educationist with administrative, authoritative or senior status.

W. L. SUMNER

\section{ENZYMES AND RELATED TOPICS}

Advances in Enzymology and Related Subjects of Biochemistry

Edited by F. F. Nord. Vol. 18. Pp. v +435.9 dollars. Vol. 19. Pp. v+457. 9.85 dollars. (New York: Interscience Publishers, Inc.; London: Interscience Publishers, Ltd., 1957.)

THESE two volumes contain a pleasing selection of the several types of review for which "Advances in Enzymology" have acquired such an excellent reputation. Of the fourteen articles, two are detailed accounts of work on a single pure enzyme; seven discuss enzymes in connexion with particular meta. bolic systems, such as the tricarboxylic acid cycle, photosynthesis, or nitrogen metabolism; three are not specifically concerned with enzymes, but with related topics, namely, cytochromes, lipoic acid, and deoxyribonucleoprotein; and one deals with a group of enzyme inhibitors. In addition, the compilers of these volumes have followed an early tradition of including an occasional article on a process in which enzymes must surely be involved, although as yet virtually nothing is known of the enzymic stages; in this instance by including an article on lignification.

In Volume 18 the pure enzyme discussed is succinic dehydrogenase. Drs. Singer, Kearney and Massey give a clear account primarily of their own recent work on the purification and properties of this flavoprotein. Particularly interesting is their discussion of the role in this system of the iron associated with the flavin group; they suggest that the iron may be functional in some reactions catalysed by the enzyme but not in others. Next to this article is an excellent review by Dr. E. F. Hartree of the cytochromes in higher plants, most of which, of course, 